\title{
Differentiation of Populations
}

\author{
Paul R. Ehrlich; Peter H. Raven \\ Science, New Series, Vol. 165, No. 3899. (Sep. 19, 1969), pp. 1228-1232.
}

Stable URL:

http://links.jstor.org/sici?sici=0036-8075\%2819690919\%293\%3A165\%3A3899\%3C1228\%3ADOP\%3E2.0.CO\%3B2-Q

Science is currently published by American Association for the Advancement of Science.

Your use of the JSTOR archive indicates your acceptance of JSTOR's Terms and Conditions of Use, available at

http://www.jstor.org/about/terms.html. JSTOR's Terms and Conditions of Use provides, in part, that unless you have obtained prior permission, you may not download an entire issue of a journal or multiple copies of articles, and you may use content in the JSTOR archive only for your personal, non-commercial use.

Please contact the publisher regarding any further use of this work. Publisher contact information may be obtained at http://www.jstor.org/journals/aaas.html.

Each copy of any part of a JSTOR transmission must contain the same copyright notice that appears on the screen or printed page of such transmission.

The JSTOR Archive is a trusted digital repository providing for long-term preservation and access to leading academic journals and scholarly literature from around the world. The Archive is supported by libraries, scholarly societies, publishers, and foundations. It is an initiative of JSTOR, a not-for-profit organization with a mission to help the scholarly community take advantage of advances in technology. For more information regarding JSTOR, please contact support@jstor.org. 


\section{Differentiation of Populations}

\author{
Gene flow seems to be less important in speciation \\ than the neo-Darwinians thought.
}

Paul R. Ehrlich and Peter H. Raven

\begin{abstract}
Most contemporary biologists think of species as evolutionary units held together by gene flow. For instance Mayr (1) writes "The nonarbitrariness of the biological species is the result of ... internal cohesion of the gene pool." Merrell (2) states "The species is a natural biological unit tied together by bonds of mating and sharing a common gene pool." This idea is founded in the pioneering work of Dobzhansky, Mayr, Stebbins, and others integrating the theory of population genetics with laboratory and field experiments and observations to produce the neo-Darwinian or synthetic theory of evolution. These workers quite logically concluded that differentiation of populations would be prevented by gene flow, and they focused their discussions of speciation on various means of interrupting that flow. In other words, they emphasized the role of mechanisms isolating populations from one another. Until quite recently there has been little reason to question this view. In the past few years, however, growing evidence from field experiments has led us to reevaluate the processes leading to organic diversity, and to conclude that a revision of this section of evolutionary theory is in order.
\end{abstract}

In this paper we suggest that many, if not most, species are not evolutionary units, except in the sense that they (like genera, families, and so forth) are products of evolution. We will argue that selection is both the primary cohesive and disruptive force in evolution, and that the selective regime itself determines what influence gene flow (or isolation) will have. Threefold evidence is presented for this. We will show that (i) gene flow in nature is much more restricted than commonly thought; (ii) populations that have been completely amount of gene flow at which significant sharing occurs. That is, we must find the amount at which subpopulations of a species affect the evolution of other subpopulations. Both questions are difficult to answer, but at least a general picture of patterns of gene flow in nature has started to emerge recently.

\section{Movement and Gene Flow \\ in Animals}

For many animals there is information on the movement of individuals. For instance, butterflies (except those few species which are migratory) seem to be quite sedentary as compared with what one might expect in view of their powers of movement (6). Birds also often seem to show less movement than they are capable of-the young of migratory species often nest near the parental nest site (7). There also is some evidence that birds may be stopped by "psychological barriers" (8). Similar restriction of movement not associated with insurmountable physical barriers has been observed in many nonaerial organisms, such as the rusty lizard (9). Twitty's (10) studies demonstrate that California newts show great perseverance and navigating ability in returning precisely to a particular stretch of stream to breed. Individuals displaced several miles in mountainous country have successfully returned to their "home pool." And, of course, the great accuracy with which salmon return to their birthplace to breed is well documented (11).

On the other hand, there also is abundant evidence in the literature that individuals may travel very long distances, such as in Bishopp and Laake's (12) release-recapture experiments with flies in which individuals were recovered as far as 17 miles $(27 \mathrm{~km})$ from the point of release. Small wind-dispersed terrestrial organisms may travel tremendous distances, as may some mammals (13). It is also clear (14) that extremely careful work covering the entire life history under a variety of weather conditions is necessary before reasonably definitive statements on amounts of individual movement may be made.

of course, movement of individuals does not necessarily indicate gene flow. Anderson (15) has shown that the pres-

The authors are professor and associate professor of biology, respectively, at the Departmen of Biological Sciences, Stanford University, Stanford, California 94305. much gene flow ordinarily occurs in nature. Second, we must determine the 
ence of wandering individuals of Mus musculus as emigrants from granary populations does not indicate significant gene flow, since in general the granary demes do not admit immigrants. Ehrlich and his co-workers (16) have produced evidence indicating that the reproductive success of emigrant Euphydryas editha individuals is less than that of stay-at-homes, a situation which also probably pertains among small mammal populations (17).

Even reproduction by migrants or propagules may not constitute evolutionarily significant gene flow. Only if the migrants are carriers of alleles or arrangements of alleles not represented in the recipient population has gene flow occurred. In addition, if a new allele is to be passed from population to population by gene flow, one must consider the probability of its spread in each new population and its possibility of being included in the genome of migrant individuals leaving that population. Its fate in the first instance will presumably be governed by the kind of gloomy odds facing mutant genes (18); in no small part it will rest with its fitness in that population. One would normally expect selective barriers to the movement of genetic novelties.

\section{Movement and Gene Flow in Plants}

In plants, we have some actual estimates of gene flow between populations. Here the chances of crossing diminish rapidly with distance. In wind-pollinated species, one might expect a great deal of gene flow even between wellseparated populations, but this assumption is not borne out by the available data. In Zea mays and Beta vulgaris, whose pollen is carried far and wide by wind, measurements have been made of contamination because of their agricultural importance. At distances greater than 60 feet $(18.3 \mathrm{~m})$, contamination by distant outcrossing in Zea was only 1 percent. In Beta plants separated by 200 meters, contamination was only 0.3 percent (19). Colwell (20) studied the dispersal of pollen of Coulter pine (Pinus coulteri) labeled with radioactive phosphorus. The bulk of the dispersal was within 10 to 30 feet $(3$ to $9 \mathrm{~m}$ ) downwind from the source, with very little beyond 150 feet $(46 \mathrm{~m})$. It is obvious that, although pollen can be dispersed great distances at times, the chances of its falling on a receptive stigma at any great distance are slight.
On the other hand, a given plant normally will be completely pollinated, even in an outcrossing species, with pollen from nearby sources. A very short distance therefore will form the basis for nearly complete genetic discontinuity, even in a wind-pollinated plant.

In insect-pollinated species, Bateman (21) found that beyond 50 feet $(15 \mathrm{~m})$ there was less than 1 percent contamination between two varieties of turnips or radishes. Similarly, Roberts and Lewis (22) cite examples in several species of the herbs of the genera Clarkia and Delphinium where no more than 50 feet $(15 \mathrm{~m})$ seems to be an effective barrier. In Linanthus parryae the pattern of variation suggests that a very short distance effectively isolates these insect-pollinated plants (23). On the other hand, insects may occasionally carry pollen to somewhat greater distances. Because of their relative specificity, they actually may do so at a much higher frequency than occurs in plants whose pollen is carried by wind. An interesting demonstration of this is provided by Emerson's (24) studies of Oenothera organensis. This species is a local endemic of the Organ Mountains in New Mexico, where it occurs in isolated small colonies in the bottom of several steep-walled canyons. The colonies are separated by high ridges and are from 600 feet $(183 \mathrm{~m})$ to about 3 miles $(5 \mathrm{~km})$ apart. Emerson was able to demonstrate that this species had a system of self-sterility $(S)$ alleles, the majority of which occurred in more than one colony, and some of which occurred in all of the colonies. Wright's (25) analysis of these data led to the conclusion that intergroup crossing had to have occurred about 2 percent of the time to account for this distribution. The plants are pollinated by strong-flying hawkmoths (Sphingidae), and Gregory (26) believes that this figure is consistent with the known behavior and power of flight of these insects.

In tropical rain forest, trees of a given species are often separated by considerable distances. Here it would appear that either strong-flying selective pollinators must actively seek out individuals or self-pollination must be prevalent. It is of interest to distinguish between these two possibilities, but little is understood of the structure of tree populations in the tropical rain forest at present.

In plants, therefore, there is consid- erable evidence that distances of from 50 feet $(15 \mathrm{~m})$ to a few miles (several kilometers) may effectively isolate populations, and there is no evidence of longer-range gene flow. Beyond these limits, there is no suggestion of gene flow at or near the amounts suggested as "normal" by Mayr (4).

The possibilities of gene flow between natural populations of most species are sharply limited by their wide separation. Both plants and animals are usually highly colonial, the populations being separated by relatively great distances. For example, colonies of the butterfly Euphydryas editha occur scattered throughout California, many of them separated by distances of several kilometers and some by gaps of nearly 200 kilometers. It has been demonstrated that there is almost no gene flow in this species over gaps of as little as 100 meters (27). For this reason, there seems no possibility that gene flow "holds together" its widely scattered populations. The cave-dwelling collembolan Pseudosinella hirsuta occurs in a series of populations in the southeastern United States. There is no gene flow between them (28), yet they resemble one another. Clarkia rhomboidea occurs in the Great Basin of the western United States as a disjunct series of similar populations in widely separated mountain ranges. These are separated by gaps of scores or hundreds of kilometers and they are genetically highly differentiated (29). Gene flow can have no bearing on their evolution under present conditions, and we suggest that these three examples are representative of the vast majority of plant and animal distributions.

What then is the evidence for gene flow as a cohesive force holding together plant and animal species? Basically, the evidence seems to be that they are "held together"-populations considered to belong to a given species resemble one another. But the taxonomic decision to consider them members of one species is inevitably based on the fact that they do resemble one another and does not in itself provide an explanation for the resemblance. It may be that in certain continuously distributed species-if there are suchthe regular exchange of genes between populations prevents differentiation in the face of different kinds of selection pressures at different places. But such a situation has never, to our knowledge, been demonstrated convincingly in either plants or animals. 


\section{The Origin of Species}

One can see that, at the very least, it is unwise to view species of sexual organisms in general as the largest group of organisms sharing a common gene pool, although it may be true in particular instances. Yet this notion is important in the history of evolutionary biology, because it has promoted the idea that a species is an evolutionary unit, and that gene flow among its populations makes it such a unit. It led also to the conclusion that sharing the gene pool gives a species "cohesion" which must be broken if further speciation is to occur.

It is appropriate now to consider what processes are critical to the multiplication of species. There is an abundance of inferential evidence indicating that, at least in many cases, gene flow is of little or no importance in maintaining many of the phenetic units we call "species." Some of the strongest evidence, of course, comes from the wide variety of organisms with asexual reproduction. When this is obligate there is, by definition, no gene flow either within or between populations. And yet these organisms tend to occur as phenetic species-presumably groups of individuals being kept similar by their continued existence under similar selective regimes. And, as Mayr (30) points out, the existence of groups of sibling species indicates that gene flow is not necessarily the cause of phenotypic uniformity.

It is not necessary, however, to turn to asexual organisms (with, presumably, sharply restricted genetic variability) or sibling species to find evidence of selection rather than gene flow maintaining phenetic units. This is clearly what is happening in Euphydryas editha in California as well as in many other butterflies with populations that are totally isolated from one another. Erebia theano populations in Alaska are only slightly differentiated from those isolated in Colorado, indeed from those in Europe. Yet we would be greatly surprised if the Colorado populations (occurring as scattered isolates) receive a gene originating in Alaska once per hundred millennia. Lycaena phlaeas remains Lycaena phlaeas in the Sierra Nevada of California, although almost certainly no alleles from its European or eastern American relatives have reached this area for thousands of generations. The sand crab Emerita ana$\log a$ has a strongly disjunct NorthernSouthern Hemisphere distribution with apparently no possibility of significant gene flow (31). In spite of this the two populations are not obviously differentiated. This is just one of many cases of a phenomenon known to marine biogeographers as "bipolarity" (32). Similarly, many species of plants have disjunct ranges in temperate North and South America, with varying amounts of differentiation despite a distributional gap of thousands of kilometers (33). Another case in point is the extreme resemblance of the marine faunas of the east and west sides of the Isthmus of Panama, which includes organisms considered to occur as pairs of relatively undifferentiated "twin species" (32). The close resemblance of the faunas remains, although the organisms on either side of the isthmus (that is, those which are restricted to warm seas) have presumably not exchanged genes for two million generations or more. Similiarly, reef fishes often are remarkably similar throughout tropical seas, although gene flow among their populations is probably very reduced. The same can be said for plants on the numerous low atolls scattered through the Pacific. The plants which occur on them are identical everywhere, as contrasted with the plants on the high islands which present different selective regimes. Similar examples of lack of obvious differentiation in the absence of gene flow we suspect will prove to be common in all groups of organisms, just as will examples of rapid and prominent local differentiation (34) with or without gene flow.

In view of these considerations, we should reexamine the commonly observed situation in which island populations are more different from mainland populations than mainland populations are from one another. This difference is usually attributed to interruption of gene flow, but may more often be a function of a very different selective regime - for example, a milder climate-on the islands. Similar reasoning might be applied to other instances of differentiation on islands, for example, the case of the Galápagos finches (35). Isolation is always assumed to play the major role in this case, and indeed it may. But the islands, although superficially similar are ecologically very different and had depauperate faunas at the time of the original invasion (that is, there were many empty niches). Furthermore, the higher islands also show great internal diversification. If this explanation is correct, then we might expect relatively slow differentiation in the future, since much of the "ecological opportunity" is gone, and the various species have now spread over the islands.

A word is necessary here about the function of isolating mechanisms, which have received so much attention from evolutionists (36). There is now no reason whatever to believe that such mechanisms evolved to somehow "protect" the genetic integrity of species. Incompatibility arises because two populations are subjected to differing selective regimes, and it is often reinforced by selection operating against hybrids. It is a common but not universal result, not a cause, of the process of speciation.

The similarity of populations that are obviously isolated from one another is conventionally attributed to their existence under similar selective regimes. But similarity where isolation is thought not to have been of long duration, or where isolation is not obvious, is almost always attributed to gene flow. This assumption seems untenable in the light of our knowledge of how rapidly differentiation can occur, gene flow or no, when selection promotes it. Biston betularia in England in 1825 would doubtless have been considered to be uniform in appearance because its populations were exchanging genes. We now know how fallacious that conclusion would have been, since whatever level of gene flow existed was insufficient to prevent dramatic local differentiation when the selective situation changed (37). Similarly the butterfly Maniola jurtina maintains stable genetic configurations selectively over vast areas (38) and maintains sharp borders between the different types in spite of strong gene flow (39). Genetic "area effects" are also well known in Cepaea populations (40) with boundaries not coinciding with barriers to gene flow.

The formation of very local races of plants and animals is commonplace even in extreme outcrossers such as the self-incompatible wind-pollinated grasses Festuca rubra and Agrostis tenuis (41). Such races, which may be sharply differentiated genetically, may occupy areas in nature only a meter or so in diameter-with these races surrounded by plants of another race. The differentiation of such localized populations dependent on the interplay between natural selection, the breeding system, and gene flow, has been analyzed (42). The advantage of particular genotypes in reproducing under a particular, often extremely local, set of conditions may be such that recombinants and other 
variants are systematically eliminated. In spite of the opportunity for high levels of gene flow, the selection pressures determined experimentally in such cases seem theoretically adequate to explain the very local patterns of differentiation found, for example, in Agrostis stolonifera (43).

The increasingly refined methods of genetic analysis that are being applied to natural populations are revealing more and more instances of unexpectedly local differentiation even when the organisms concerned are highly mobile and the populations appear to be continuous. In Drosophila aldrichi, Richardson (44) analyzed three populations within a 40-mile $(64 \mathrm{~km})$ radius of Austin, Texas, for the frequencies of six alleles concerned with a particular esterase system. The frequencies differed slightly from locality to locality but remained constant at each locality during a year. Using a similar approach, Selander (45) showed "microgeographic" variation between populations of the house mouse (Mus musculus) in a single large barn.

Thus, there is increasing evidence of extremely local patterns of differentiation in both plants and animals. We predict that such patterns may prove to be the rule, rather than the exception, for most populations of organisms.

Evidence from natural populations is supported by experimental work such as that of Thoday and his co-workers (46) which indicates that selection can override the effects of gene flow even when the amount of that flow is greater than would ever occur in nature. Evidence of this sort would undermine arguments about "gene flow" as a cohesive force binding together all the populations of some widespread species into a genetic entity, even if such binding were not patently impossible for most organisms on purely distributional grounds. Indeed, gene flow eventually might be discovered to play a rather insignificant role in evolution as a whole. There is substantial evidence that populations can be changed rapidly by selection. Similarly there is evidence that selection often resists such change-presumably in part because of genetic homeostasis. The most basic forces involved in the differentiation of populations may be antagonistic selective strategies, one for close "tracking" of the environment and one for maintaining "coadapted" genetic combinations-combinations which have high average fitness in environments which are inevitably variable through time.

19 SEPTEMBER 1969
Of course final answers about the relative evolutionary roles of selection and gene flow will not come until we have more thorough studies of natural situations. Some of the cases commonly presented as showing gene flow preventing differentiation need careful reexamination, for example, those of Hooper (47) and others on the development of dark-lava races in mice. If this, indeed, is a case of gene flow swamping selection, then we must learn the magnitude of both factors. In cases such as that of Euphydryas editha, laboratory and field experiments must be devised to determine the exact selective regimes which produce relative uniformity among populations along with temporal variability within populations, in the absence of gene flow. In this, and virtually all other situations cited in this paper, further genetic analysis is needed to determine how well phenetic uniformity or variability reflects genetic uniformity or variability. It is well known that there is no one-to-one relationship (48), but in general we are profoundly ignorant of the degree of overall genetic similarity, however defined (49), at all levels of phenetic differentiation.

Our suspicion is that, eventually, we will find that, in some species, gene flow is an important factor in keeping populations of the species relatively undifferentiated, but that in most it is not. As this becomes widely recognized we will see the disappearance of the idea that species, as groups of actually or potentially interbreeding populations, are evolutionary units "required" by theory. Modern evolutionary theory requires local interbreeding populations, far smaller groups than those normally called species, as evolutionary units in sexual organisms. It recognizes that such units will vary greatly in their genetic properties and may have a vast diversity of relationships with other such units. The evolution of larger phenetic clusters-the species, genera, orders, and so forth, of taxonomistsis easily derived from the theory, but it seems unwise to consider any of these as evolutionary units except in those cases where they can be shown to react to evolutionary pressures as units $(50)$.

\section{Summary}

Evidence is presented from a variety of sources which indicates that species should not be thought of as evolutionary units held together by the cohe- sive force of gene flow. Gene flow in nature is much more restricted than commonly thought and experimental evidence is badly needed to document the extent to which it does occur. Selection itself is both the primary cohesive and disruptive force in evolution; the selective regime determines what influence gene flow has on observed patterns of differentiation. Populations will differentiate if they are subjected to different selective forces and will tend to remain similar if they are not. For sexual organisms it is the local interbreeding population and not the species that is clearly the evolutionary unit of importance.

\section{References and Notes}

1. E. Mayr, Animal Species and Evolution (Harvard Univ. Press, Cambridge, Mass., 1963), p. 21.

2. D. J. Merrell, Evolution and Genetics (Holt, Rinehart \& Winston, 1962), p. 293.

3. P. H. Raven, Univ. Calif. Publ. Bot. 34, 1 (1962); P. R. Ehrlich and R. W. Holm, Science 137, 652 (1962); P. R. Ehrlich, Syst. Zool. 13, 109 (1964)

4. E. Mayr, Animal Species and Evolution (Harvard Univ. Press, Cambridge, Mass., $1963)$, pp. 521 and 177

5. More work like that of H. L. Carson [Evolution 15, $496(1961)]$ on the possible effects of single migrants or small groups of migrants is badly needed.

6. P. R. Ehrlich, Science 154, 108 (1961).

7. M. N. Nice, Trans. Linn. Soc. N.Y. 4, 1 (1937).

8. E. Mayr, Systematics and the Origin of Species (Columbia Univ. Press, New York, 1942).

9. W. F. Blair, The Rusty Lizard, a Population Study (Univ. of Texas Press, Austin, 1960)

10. V. C. Twitty, Science 130, 1735 (1959).

11. F. Neave, J. I. Manzer, H. Godfrey, R. J. Brasseur, Fish Res. Bd. Can. Rep. No. 563 (1962).

12. F. C. Bishopp and E. W. Laake, J. Agr. Res. 21, 729 (1921).

13. See, for example, N. P. Naumov, Proc. Symposium Thereologicum (Prague, 1960), p. 221.

14. See, for example, W. G. Wellington, Can. J. Zool. 38, 289 (1960)

15. P. K. Anderson, unpublished data.

16. P. R. Ehrlich, unpublished data; P. Labine, Evolution 20, 580 (1966).

17. P. L. Errington, Muskrat Populations (Iowa State Univ. Press, Ames, 1963).

18. R. A. Fisher, The Genetical Theory of Natural Selection (Clarendon Press, Oxford, 1930).

19. A. Archimowitsch, Bot. Rev. 15, 613 (1949); A. J. Bateman, Heredity 1, 235 (1947).

20. R. N. Colwell, Amer. J. Bot. 38, 511 (1951).

21. A. J. Bateman, Nature 157, 752 (1946).

22. M. R. Roberts and H. Lewis, Evolution 9, 445 (1955).

23. C. Epling, H. Lewis, F. M. Ball, ibid. 14, 238 (1960).

24. S. Emerson, Genetics 23, 190 (1938); ibid. 24, 524 (1939).

25. S. Wright, ibid., p. 538.

25. S. Wright, ibid., p. 538.

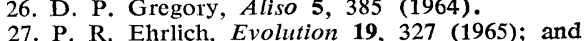
P. R. Ehrlich, Ev
unpublished data.

28. K. Christiansen and D. Culver, Evolution 22, 237 (1968)

29. T. Mosquin, ibid. 18, 12 (1964).

30. E. Mayr, Animal Species and Evolution (Harvard Univ. Press, Cambridge, Mass., 1963), p. 521.

31. L. Eickstaedt, personal communications.

32. S. Ekman, Zoogeography of the Sea (Sedgwick and Jackson, London, 1953).

33. P. H. Raven, Quart. Rev. Biol. 38, 151 (1963).

34. See, for example, R. F. Johnson and R. K. Selander, Science 144, 548 (1964); E. Stodard, CSIRO (Commonw. Sci. Ind. Res. Organ.) 
Wildlife Res. 10, 73 (1966); G. C. Packard, Syst. Zool. 16, 73 (1967); A. D. Bradshaw, Nature 169, 1098 (1952); A. P. Nelson, Brittonia 17, 160 (1965).

35. V. Lack, Darwin's Finches (Cambridge Univ. Press, Cambridge, 1947)

36. See, for example, Th. Dobzhansky, Genetics and the Origin of Species (Columbia Univ. Press, New York, ed. 2, 1951).

37. H. B. D. Kettlewell, Heredity 12, 51 (1958).

38. W. H. Dowdeswell and $K$. McWhirter, ibid 22, 187 (1967).

9. E. R. Creed, W. H. Dowdeswell, E. B. Ford J. G. McWhirter, ibid. 17, 237 (1962).

40. A. J. Cain and C. Currey, ibid. 18, 467 (1963); C. B. Goodhart, ibid., p. 459.

41. A. Smith Scot. Plant Breed. Sta. Rec. 1965 163 (1965).
42. S. K. Jain and A. D. Bradshaw, Heredity 22 , 407 (1966).

43. J. L. Aston and A. D. Bradshaw, ibid. 21, 649 (1966).

44. R. H. Richardson, Proc. Int. Congr. Genet. 2, 155 (1968)

45. R. Selander, "Behavior and genetic variation in wild populations," a paper presented in a symposium "Ecology and the Origin of Spea symposium "Ecology and the Origin of Species" at the 1960

46. See, for example, J. M. Thoday, Heredity 13, 187 (1959); $\longrightarrow$ and T. B. Boam, ibid. p. 205; J. M. Thoday and J. B. Gibson, Nature 193, 1164 (1962); J. B. Gibson and J. M. Thoday, Heredity 17, 1 (1962).

47. E. T. Hooper, Misc. Publ. Mus. Zool. Univ. Mich. 51, 1 (1941).
48. See, for example, J. M. Rendel, J. Theor Biol. 2, 296 (1962); see, however, J. L. Hubby and L. H. Throckmorton [Amer. Nat. 102, 193 (1968)], which indicates a high correlation between phenetic and "genehigh correlation be tic" differentiation.

49. P. Ehrlich, Syst. Zool. 13, 109 (1964).

50. We thank the members of the Population Biology Group of the Department of Biological Sciences, Stanford University, and numerous colleagues at other institutions for discussing and criticizing the ideas presented here. Supported in part by NSF grants GB 8038 and GB-8174 (P.R.E.) and GB-7949X (P.H.R.). A version of this paper was presented in the symposium "Ecology and the Origin of Species" at the 1968 annual meeting of the AAAS at Dallas.

\title{
Social Benefit versus Technological Risk
}

\author{
What is our society willing to pay for safety?
}

\author{
Chauncey Starr
}

The evaluation of technical approaches to solving societal problems customarily involves consideration of the relationship between potential technical performance and the required investment of societal resources. Although such performance-versus-cost relationships are clearly useful for choosing between alternative solutions, they do not by themselves determine how much technology a society can justifiably purchase. This latter determination requires, additionally, knowledge of the relationship between social benefit and justified social cost. The two relationships may then be used jointly to determine the optimum investment of societal resources in a technological approach to a social need.

Technological analyses for disclosing the relationship between expected performance and monetary costs are a traditional part of all engineering planning and design. The inclusion in such studies of all societal costs (indirect as well as direct) is less customary, and obviously makes the analysis more difficult and less definitive. Analyses of social value as a function of technical

The author is dean of the School of Engineering and Applied Science, University of California, Los Angeles. This article is adapted from a paper presented at the Symposium on Human Ecology held at Airlie House, Warrenton, Virginia, in November 1968 performance are not only uncommon but are rarely quantitative. Yet we know that implicit in every nonarbitrary national decision on the use of technology is a trade-off of societal benefits and societal costs.

In this article I offer an approach for establishing a quantitative measure of benefit relative to cost for an important element in our spectrum of social values-specifically, for accidental deaths arising from technological developments in public use. The analysis is based on two assumptions. The first is that historical national accident records are adequate for revealing consistent patterns of fatalities in the public use of technology. (That this may not always be so is evidenced by the paucity of data relating to the effects of environmental pollution.) The second assumption is that such historically revealed social preferences and costs are sufficiently enduring to permit their use for predictive purposes.

In the absence of economic or sociological theory which might give better results, this empirical approach provides some interesting insights into accepted social values relative to personal risk. Because this methodology is based on historical data, it does not serve to distinguish what is "best" for society from what is "traditionally acceptable."

\section{Maximum Benefit at Minimum Cost}

The broad societal benefits of advances in technology exceed the associated costs sufficiently to make technological growth inexorable. Shef's socioeconomic study (1) has indicated that technological growth has been generally exponential in this century, doubling every 20 years in nations having advanced technology. Such technological growth has apparently stimulated a parallel growth in socioeconomic benefits and a slower associated growth in social costs.

The conventional socioeconomic benefits-health, education, income-are presumably indicative of an improvement in the "quality of life." The cost of this socioeconomic progress shows up in all the negative indicators of our society-urban and environmental problems, technological unemployment, poor physical and mental health, and so on. If we understood quantitatively the causal relationships between specific technological developments and societal values, both positive and negative, we might deliberately guide and regulate technological developments so as to achieve maximum social benefit at minimum social cost. Unfortunately, we have not as yet developed such a predictive system analysis. As a result, our society historically has arrived at acceptable balances of technological benefit and social cost empirically-by trial, error, and subsequent corrective steps.

In advanced societies today, this historical empirical approach creates an increasingly critical situation, for two basic reasons. The first is the wellknown difficulty in changing a technical subsystem of our society once it has been woven into the economic, political, and cultural structures. For example, many of our environmental-pollution problems have known engineering 
http://www.jstor.org

\title{
LINKED CITATIONS
}

\author{
- Page 1 of 3 -
}

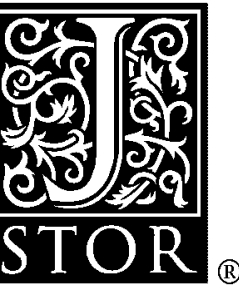

You have printed the following article:

\section{Differentiation of Populations}

Paul R. Ehrlich; Peter H. Raven

Science, New Series, Vol. 165, No. 3899. (Sep. 19, 1969), pp. 1228-1232.

Stable URL:

http://links.jstor.org/sici?sici=0036-8075\%2819690919\%293\%3A165\%3A3899\%3C1228\%3ADOP\%3E2.0.CO\%3B2-Q

This article references the following linked citations. If you are trying to access articles from an off-campus location, you may be required to first logon via your library web site to access JSTOR. Please visit your library's website or contact a librarian to learn about options for remote access to JSTOR.

\section{References and Notes}

\section{${ }^{3}$ Patterns and Populations}

Paul R. Ehrlich; Richard W. Holm

Science, New Series, Vol. 137, No. 3531. (Aug. 31, 1962), pp. 652-657.

Stable URL:

http://links.jstor.org/sici?sici=0036-8075\%2819620831\%293\%3A137\%3A3531\%3C652\%3APAP\%3E2.0.CO\%3B2-Z

\section{${ }^{5}$ Heterosis and Fitness in Experimental Populations of Drosophila melanogaster}

Hampton L. Carson

Evolution, Vol. 15, No. 4. (Dec., 1961), pp. 496-509.

Stable URL:

http://links.jstor.org/sici?sici=0014-3820\%28196112\%2915\%3A4\%3C496\%3AHAFIEP\%3E2.0.CO\%3B2-S

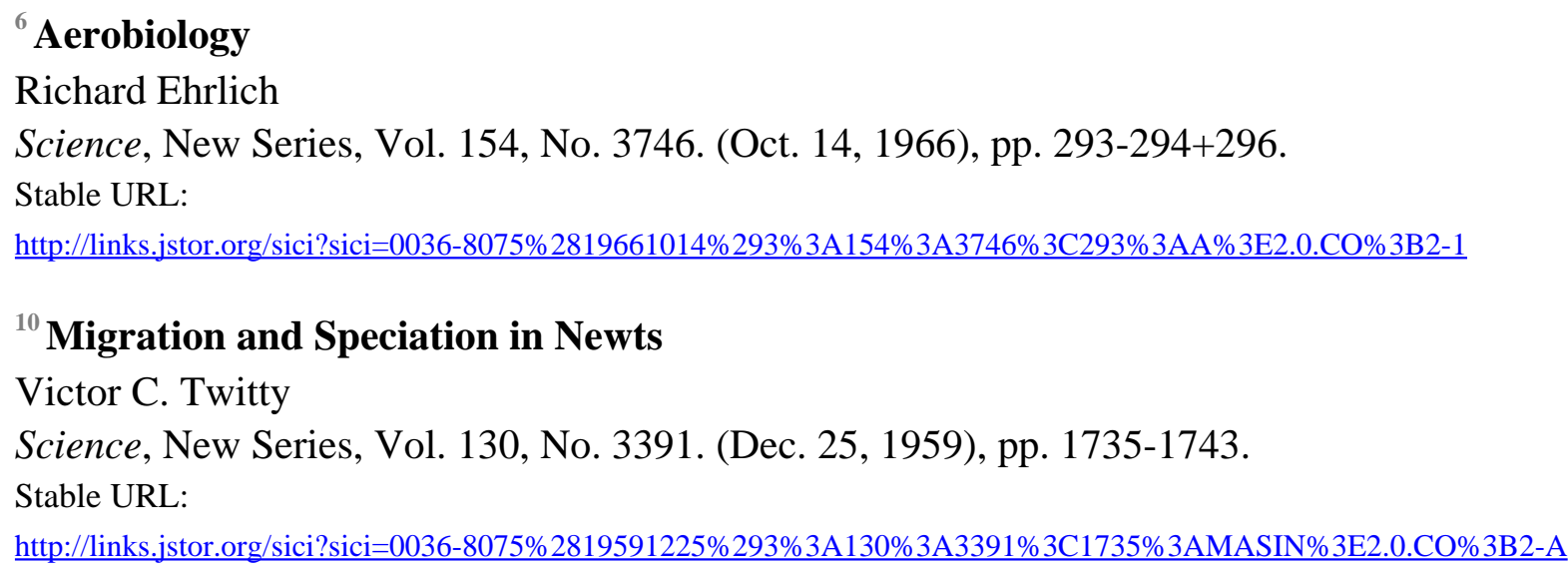

NOTE: The reference numbering from the original has been maintained in this citation list. 
http://www.jstor.org

\section{LINKED CITATIONS}

- Page 2 of 3 -

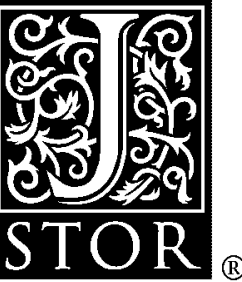

\footnotetext{
${ }^{16}$ The Population Biology of the Butterfly, Euphydryas editha. IV. Sperm Precedence-A Preliminary Report

Patricia A. Labine

Evolution, Vol. 20, No. 4. (Dec., 1966), pp. 580-586.

Stable URL:

http://links.jstor.org/sici?sici=0014-3820\%28196612\%2920\%3A4\%3C580\%3ATPBOTB\%3E2.0.CO\%3B2-G

${ }^{22}$ Subspeciation in Clarkia biloba

Margaret R. Roberts; Harlan Lewis

Evolution, Vol. 9, No. 4. (Dec., 1955), pp. 445-454.

Stable URL:

http://links.jstor.org/sici?sici=0014-3820\%28195512\%299\%3A4\%3C445\%3ASICB\%3E2.0.CO\%3B2-J
}

${ }^{27}$ The Population Biology of the Butterfly, Euphydryas editha. II. The Structure of the Jasper Ridge Colony

Paul R. Ehrlich

Evolution, Vol. 19, No. 3. (Sep., 1965), pp. 327-336.

Stable URL:

http://links.jstor.org/sici?sici=0014-3820\%28196509\%2919\%3A3\%3C327\%3ATPBOTB\%3E2.0.CO\%3B2-7

${ }^{28}$ Geographical Variation and Evolution in Pseudosinella hirsuta

Kenneth Christiansen; David Culver

Evolution, Vol. 22, No. 2. (Jun., 1968), pp. 237-255.

Stable URL:

http://links.jstor.org/sici?sici=0014-3820\%28196806\%2922\%3A2\%3C237\%3AGVAEIP\%3E2.0.CO\%3B2-5

${ }^{33}$ Amphitropical Relationships in the Floras of North and South America
Peter H. Raven
The Quarterly Review of Biology, Vol. 38, No. 2. (Jun., 1963), pp. 151-177.
Stable URL:
http://links.jstor.org/sici?sici=0033-5770\%28196306\%2938\%3A2\%3C151\%3AARITFO\%3E2.0.CO\%3B2-1

${ }^{34}$ Human Blood Group A 1 Specific Agglutinin of the Butter Clam Saxidomus giganteus Howard M. Johnson

Science, New Series, Vol. 146, No. 3643. (Oct. 23, 1964), pp. 548-549.

Stable URL:

http://links.jstor.org/sici?sici=0036-8075\%2819641023\%293\%3A146\%3A3643\%3C548\%3AHBGASA\%3E2.0.CO\%3B2-Q

NOTE: The reference numbering from the original has been maintained in this citation list. 
http://www.jstor.org

\section{LINKED CITATIONS \\ - Page 3 of 3 -}

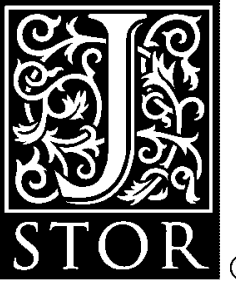

${ }^{34}$ Taxonomic and Evolutionary Implications of Lawn Races in Prunella Vulgaris (Labiatae) Andrew P. Nelson

Brittonia, Vol. 17, No. 2. (Apr., 1965), pp. 160-174.

Stable URL:

http://links.jstor.org/sici?sici=0007-196X\%28196504\%2917\%3A2\%3C160\%3ATAEIOL\%3E2.0.CO\%3B2-9

NOTE: The reference numbering from the original has been maintained in this citation list. 